\author{
Review / Derleme
}

\title{
Decidua and gestational trophoblastic neoplasia: a review
}

\author{
Desidua ve gestasyonel neoplazi: derleme
}

Ali Çetin, MD ${ }^{1}$, Meral Çetin, MD, Çağlar Yıldız, MD

Department of Obstetrics and Gynecology (Prof. Ali Çetin, MD; Prof. Meral Çetin, MD; Cağlar Yıldız, MD, Obstetrician and Gynecologist), Cumhuriyet University School of Medicine, 58140 Sivas

\begin{abstract}
The normal endometrium changes after implantation of an embryo. Decidua is the term for the endometrium during a pregnancy, which is formed under the influence of progesterone as the maternal part of the placenta. It has a histologically distinct appearance, displaying large polygonal decidual cells in the stroma. These are enlarged endometrial stromal cells, which resemble epithelium. Interaction of decidua and trophoblasts causes many physiologic and pathopysiologic changes in the uterine cavity. Imaging of decidua and trophoblastic tissues by ultrasound is an important aspect of diagnostic workout in obstetrics and gynecology.
\end{abstract}

Keywords: Decidua, endometrium, placenta, pregnancy, ultrasonography, imaging

\section{Özet}

Normal endometrium embriyonun implantasyonundan sonra değişir. Progesteron etkisi altında plasentanın anne tarafını oluşturan endometriuma gebelikte desidua denir. Stromasında büyük poligonal hücreler olması karakteristik özelliğidir. Bu hücreler epitele benzeyen büyümüş endometrial stromal hücrelerdir. Desidua ve trofoblastların ilişkisi uterin kavited birçok fizyolojik ve patofizyolojik değişikliğe neden olur. Jinekoloji ve doğum biliminin klinik uygulamasında ultrasonografi ile desidua ve trofoblastik dokuların görüntülenmesi tanısal işlemlerin önemli bir kısmını oluşturur.

\footnotetext{
${ }^{1}$ Corresponding author:

Dr. Ali Çetin, Kadın Hastalıkları ve Doğum Anabilim Dalı, Cumhuriyet Üniversitesi Tıp

Fakültesi, TR-58140 Sivas

Email: dralicetin@yahoo.com
} 
Anahtar sözcükler: Desidua, endometrium, plasenta, gebelik, ultrasonografi, görüntüleme

\section{Decidua}

During pregnancy, the glands and blood vessels in the endometrium further increase in size and number. Vascular spaces fuse and become interconnected after trophoblast invasion to form the placenta, which supplies oxygen and nutrition to the embryo and fetus. During pregnancy, progesterone plays an important role in the maintenance of pregnancy. Progesterone secreted firstly from the corpus luteum and 8 weeks later from the placenta. Maintenance of the corpus luteum of pregnancy depends on continuous stimulation by hCG secreted by the trophoblast of the developing embryo. Under the influence of hCG, the corpus luteum increases its output of progesterone, thereby stimulating secretion of fluid by endometrial glands. The hypersecretory endometrium of pregnancy shows widely dilated glands lined by cells with abundant glycogen. These features can persist for up to 8 weeks after delivery $(1,2)$.

Decidua is the term for the endometrium during a pregnancy, which is formed under the influence of progesterone as the maternal part of the placenta. It has a histologically distinct appearance, displaying large polygonal decidual cells in the stroma. These are enlarged endometrial stromal cells, which resemble epithelium. Vascularity, as well as vascular permeability, is enhanced in the decidualizing endometrium. Its leukocyte population is distinct, with the presence of large endometrial granular leukocytes, uterine natural killer cells, being predominant, while polynuclear leukocytes and B-cells are scant. It produces maternal steroid and proteins that relate directly to the maintenance and protection of the pregnancy from immunologic rejection. The syncytiotrophoblast cells invade endometrium and resorb the proteins, sugars, and lipids that have been formed there. They also erode the canals of the endometrial glands and the vessels of the stroma. Erosion of these vessels by the trophoblast fills the lacunar networks of developing placenta with maternal blood and establishes a primitive circulatory system $(3,4)$.

Decidua is divided into three areas. Decidua basalis is beneath the site of implantation of the embryo, which becomes the maternal contribution to the placenta. Decidua capsularis surrounds the remainder of the embryo and serves as a covering between the embryo and the uterine cavity. With fetal growth, the decidua capsularis bulges into the uterine cavity and fuses with the decidua parietalis. The uterine cavity is thus obliterated at the end of the first trimester. Decidua parietalis is the lining the rest of the uterus.

\section{Placenta Accreta}

Placenta accreta is an abnormal partial or total adherence of the placenta to the uterine wall. In placenta accreta, the placenta adheres directly to the myometrium with either defective decidua or no deciduas in between. When the chorionic villi extend further than contact with the myometrium and actually penetrate the uterine wall, the 
condition is called placenta increta. Placenta percreta occurs when the chorionic villi invade through the entire uterine wall to the peritoneal layer. These conditions are rare complications, although there is an increased incidence of placenta accreta when the woman has placenta previa, previous cesarean section, or an unexplained elevated MSAFP. A complete placenta accreta has no signs and symptoms. It is discovered during attempted manual removal of the retained placenta $(2,5)$.

\section{Retained Products of Conception}

The management of patients with postabortal bleeding and abdominal pain still presents a major clinical challenge. In the treatment of first trimester spontaneous abortion, clinically thought to be incomplete or complete, the conventional management is elective curettage to prevent complications that may arise from retained products of conception. However, TVS is a simple and effective method for the evaluation of residual trophoblastic tissue in patients presenting with postabortal symptoms and for the elimination of unnecessary curettage procedures (6). Cetin and Cetin (6) performed TVS for possible retained products of conception and measured the maximum anteroposterior diameter of the uterine cavity on the long axis view during initial examination of patients presenting with postabortal bleeding: those with a normal uterine cavity or a uterine cavity with fluid collection without echogenic foci considered not to have retained products of conception, and those with a uterine cavity containing solid components with or without intrauterine fluid were considered to have retained products of conception. They concluded that conservative management can be a choice in patients with a uterine cavity containing no solid component, solid component with fluid and diameter of uterine cavity less than $10 \mathrm{~mm}$, and only solid component and uterine cavity less than $8 \mathrm{~mm}$.

\section{Gestational Trophoblastic Disease}

Gestational trophoblastic disease (GTD) comprises a unique group of human neoplastic diseases that derive from fetal trophoblastic tissues and represent semiallografts in patients. It can occur after any type of antecedent pregnancy including term or preterm pregnancy, spontaneous or induced miscarriages, ectopic pregnancy, and molar pregnancy. Table 1 presents selected characteristics of GTD. GTD can be benign or malignant, and those that invade locally or metastasize are collectively known as gestational trophoblastic neoplasia (GTN). Histologically, GTD is classified into hydatidiform moles, invasive mole, choriocarcinoma, and intermediate trophoblastic tumors and tumor-like lesions. Intermediate trophoblastic tumor-like lesions are benign and invasive mole, choriocarcinoma, and intermediate trophoblastic tumors are malignant, however, a hydatidiform mole can behave in a benign or malignant fashion. Several laboratory and radiological tools are available to secure the clinical diagnosis of GTT and determine extent of disease. Serial measurements of serum hCG are essential for reliable diagnosis and are the foundation upon which individualized therapeutic decisions are built. In general, serum hCG levels correspond to tumor burden (7). 
Table 1. Characteristics of gestational trophoblastic diseases.

\begin{tabular}{|c|c|c|c|c|c|c|c|}
\hline & $\begin{array}{l}\frac{c}{00} \\
\frac{.0}{0} \\
\frac{1}{0} \\
\frac{0}{5} \\
\overline{\bar{U}} \\
\end{array}$ & 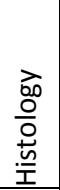 & 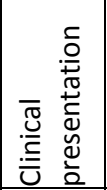 & 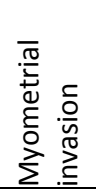 & 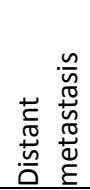 & 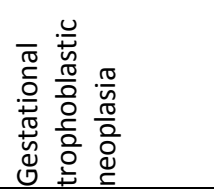 & $\begin{array}{l}\frac{\partial}{\frac{0}{0}} \\
\frac{\sqrt{0}}{2} \\
\frac{0}{5}\end{array}$ \\
\hline $\begin{array}{l}\text { Exaggerated } \\
\text { placental reaction }\end{array}$ & $\begin{array}{l}\text { Implantation-site } \\
\text { intermediate } \\
\text { trophoblasts with a } \\
\text { infiltrative growth } \\
\text { pattern } \\
\end{array}$ & $\mathrm{Bn}$ & $\mathrm{Bn}$ & Yes & No & No & No \\
\hline $\begin{array}{l}\text { Placental-site } \\
\text { nodule }\end{array}$ & $\begin{array}{l}\text { Chorionic-type } \\
\text { intermediate } \\
\text { trophoblasts with a } \\
\text { nodular growth pattern }\end{array}$ & $\mathrm{Bn}$ & $\mathrm{Bn}$ & Yes & No & No & No \\
\hline $\begin{array}{l}\text { Complete } \\
\text { hydatidiform } \\
\text { mole }\end{array}$ & $\begin{array}{l}\text { Villous cytotrophoblast } \\
\text { and syncytiotrophoblast }\end{array}$ & $\mathrm{Bn}$ & Premn & No & No & $\begin{array}{l}\text { Premn } \\
\text { Mn } \\
\text { transformation } \\
\% 10-20\end{array}$ & $\begin{array}{l}\text { Evacuation or } \\
\text { rarely } \\
\text { hysterectomy } \\
\text { Serial hCG } \\
\text { measurements }\end{array}$ \\
\hline $\begin{array}{l}\text { Partial } \\
\text { hydatidiform } \\
\text { mole }\end{array}$ & $\begin{array}{l}\text { Villous cytotrophoblast } \\
\text { and syncytiotrophoblast }\end{array}$ & $\mathrm{Bn}$ & Premn & No & No & $\begin{array}{l}\text { Premn } \\
\text { Mn } \\
\text { transformation } \\
2 \%\end{array}$ & $\begin{array}{l}\text { Evacuation or } \\
\text { rarely } \\
\text { hysterectomy } \\
\text { Serial hCG } \\
\text { measurements } \\
\end{array}$ \\
\hline Invasive mole & $\begin{array}{l}\text { Villous cytotrophoblast } \\
\text { and syncytiotrophoblast }\end{array}$ & $\mathrm{Bn}$ & $\mathrm{Mn}$ & Yes & Yes & Yes & Chemotherapy \\
\hline Choriocarcinoma & $\begin{array}{l}\text { Cytotrophoblast, } \\
\text { syncytiotrophoblast, and } \\
\text { intermediate } \\
\text { trophoblast of the } \\
\text { previllous blastocyst }\end{array}$ & $\mathrm{Mn}$ & $M n$ & Yes & Yes & Yes & Chemotherapy \\
\hline $\begin{array}{l}\text { Placental-site } \\
\text { trophoblastic } \\
\text { tumor }\end{array}$ & $\begin{array}{l}\text { Implantation-site } \\
\text { intermediate } \\
\text { trophoblasts with a } \\
\text { infiltrative growth } \\
\text { pattern }\end{array}$ & $\mathrm{Mn}$ & $M n$ & Yes & Yes & Yes & Chemotherapy \\
\hline $\begin{array}{l}\text { Epithelioid } \\
\text { trophoblastic } \\
\text { tumor }\end{array}$ & $\begin{array}{l}\text { Chorionic-type } \\
\text { intermediate } \\
\text { trophoblasts with a } \\
\text { nodular growth pattern }\end{array}$ & $\mathrm{Mn}$ & $M n$ & Yes & Yes & Yes & Chemotherapy \\
\hline
\end{tabular}

\section{Histology}

Complete hydatidiform mole looks like placental tissue and generally shows an absence of embryonic or fetal tissue, with extensive hydatidiform swelling and trophoblastic hyperplasia. By contrast, partial hydatidiform mole is generally characterized by the presence of embryonic or fetal tissues, with limited swelling and trophoblastic hyperplasia. Complete hydatidiform mole looks like placental tissue, but edema of the villi demonstrates varying sizes. An invasive mole has the same histopathological characteristics of complete or partial hydatidiform mole, but invasion of the myometrium with necrosis and hemorrhage occurs or metastases are present. Histologically, choriocarcinomas have no villi, but they have sheets of trophoblasts and hemorrhage. Choriocarcinoma is the most common malignant form of GTN, and it is 
characterized by sheets of anaplastic cytotrophoblast and syncytiotrophoblast without chorionic villi (8).

Intermediate trophoblastic tumors and tumor-like lesions are rare forms of gestational trophoblastic neoplasia. The intermediate trophoblast (IT) is thought to have a phenotype that is between that of the primitive cytotrophoblast and the terminally differentiated syncytiotrophoblast. It is the primary cell type in intermediate trophoblastic tumor-like lesions including exaggerated placental site and placental site nodule, and intermediate trophoblastic tumors including placental site trophoblastic tumor (PSTT) and epithelioid trophoblastic tumor (ETT). Based on anatomic location in the pregnant uterus, ITs can be divided into villous, implantation-site, and chorionic subtypes. Implantation-site IT tends to have an infiltrative growth pattern, and is thought to be the cell type of origin for lesions with a similar growth pattern, including exaggerated placental site and its neoplastic counterpart, PSTT. In contrast, the chorionic-type IT has a nodular growth pattern and is thought to be the cell type of origin for lesions with this growth pattern, including placental site nodule and ETT (9). These tumors diagnosed after histological examination of specimens of endometrial curettage or hysterectomy. PSTT or ETT can also be found in resected metastatic lesions. Exaggerated placental site is a benign, nonneoplastic lesion characterized by an increased number of intermediate trophoblasts that extensively infiltrate the endometrium and underlying myometrium. Placental site nodule is a wellcircumscribed, round to oval lesion that is extensively hyalinized (10).

\section{Genetic Background}

Complete hydatidiform moles are characterized by a normal number of chromosomes, all of which are of paternal origin; about $90 \%$ arise as a result of an ovum being fertilized by a haploid $(23, X)$ sperm, which duplicates its own chromosomes $(46, X X)$ but in the remaining 10\%, a 46,XY karyotype results from dispermy. Cytogenetic assessment shows partial moles are usually characterized by a triploid karyotype (69 chromosomes), incorporating a paternally derived extra set of 23 chromosomes; these moles result from dispermic fertilization of a normal ovum. Choriocarcinomas are aneuploid and can be heterozygous, depending on the type of pregnancy from which the choriocarcinoma arose. If a hydatidiform mole preceded the choriocarcinoma, the chromosomes are of paternal origin. Maternal and paternal chromosomes are present if a term pregnancy precedes the choriocarcinoma. Of choriocarcinomas, $50 \%$ are preceded by a hydatidiform mole, $25 \%$ by an abortion, and the other $25 \%$ by a preterm or term pregnancy $(7,8)$.

\section{Hydatidiform Moles}

Hydatidiform moles are the most common form of GTD presenting as complete and partial type. They are generally considered a benign condition and can be managed initially with molar evacuation and serial measurements of serum hCG as follow-up. No methods exist to accurately predict the clinical behavior of hydatidiform moles by histopathology. The clinical course is defined by the patient's serum hCG curve after 
molar evacuation. Serum hCG levels steadily decrease to normal within 8-12 weeks after molar evacuation. After malignant transformation of the hydatidiform moles, $10-20 \%$ with complete type and $2 \%$ with partial type develop a malignant clinical behavior with a rise or plateau of serum HCG levels and diagnosed as persistent GTD. The partial hydatidiform mole that develops into persistent GTD is almost always invasive mole as opposed to choriocarcinoma $(0.1 \%)$, tending not to metastasize and responding to chemotherapy (11).

\section{Exaggerated Placental Site}

An exaggerated placental site may occur in association with normal pregnancy or an abortion. It is an exaggeration of the normal physiologic process of implantation. It involutes following termination of pregnancy, and no specific treatment or follow-up is necessary. When an exaggerated placental site cannot be confidently distinguished from PSTT by morphology and immunohistochemistry, close follow-up with serial hCG levels is advisable (12).

\section{Placental Site Nodule}

A placental site nodule is usually an incidental finding in younger women during the examination of endometrial curettage or hysterectomy specimens (12).

\section{Placental Site Trophoblastic Tumor}

PSTT is an uncommon variant of GTN and tends to remain locally invasive until late in its course, its clinical behavior remains unpredictable. PSTT does not exhibit a high degree of sensitivity to chemotherapy. The intermediate trophoblasts contain human placental lactogen (HPL). These patients have persistent low levels of serum HCG (100-1000 $\mathrm{mIU} / \mathrm{mL}$ ). The treatment of PSTTs is hysterectomy with ovarian conservation. If the tumor recurs or metastases are present at initial diagnosis, chemotherapy is administered with variable results. Radiation therapy may provide local control (13).

\section{Epithelioid Trophoblastic Tumor}

Epithelioid trophoblastic tumor is a rare form of gestational trophoblastic disease that occurs in women of reproductive age after any type of pregnancy between 1 and 18 years following a previous gestation. Definition, clinical course, and management of epithelioid trophoblastic tumor are unclear because of low incidence and paucity of reported data. Literature search revealed 52 cases of ETT (14). Abnormal vaginal bleeding is the most common clinical presentation, and serum hCG levels are always elevated at the time of diagnosis (15).

\section{Imaging Workout}

Ultrasound is the radiological investigation of choice for initial diagnosis of GTN. As well as identification of a hydatidiform mole, ultrasound should also be obtained to exclude an intrauterine pregnancy before initiating chemotherapy (16). TVS may show the interface between abnormal trophoblastic tissue and normal myometrium with higher 
resolution, and hence may allow the diagnosis of myometrial invasion (5). There can be diagnostic difficulty in distinguishing a partial hydatidiform mole from a complete hydatidiform mole and practically, the distinction is usually made histopathologically after evacuation of the molar tissue (16).

Although uterine disease is sometimes absent in patients presenting with choriocarcinoma, like invasive moles they may appear as heterogeneous, echogenic masses characterized by necrosis and haemorrhage. They are markedly hypervascular on Doppler interrogation, though in some cases endometrial, myometrial and parametrial invasion can be difficult to demonstrate. In such cases, magnetic resonance imaging (MRI) can play an important role, although it is rarely clinically necessary. Choriocarcinoma is distinguished histologically from an invasive mole by absent placental villous structures, but this distinction is seldom possible sonographically.

PSTT may also appear as a heterogeneous, hyperechoic mass with multiple cystic spaces within the myometrium of an enlarged uterus. These features alone do not allow distinction from other forms of GTN, though on Doppler both hypervascular and hypovascular forms of the disease have been described with or without cystic masses, but none of these features are diagnostic of PSTT (17).

A chest X-ray is used as a screening tool for trophoblastic metastases, and is also useful in evaluating women experiencing respiratory distress with suspected pulmonary edema, adult respiratory distress syndrome, or extensive lung metastases. Chest $\mathrm{CT}$ is more sensitive than chest X-ray for detecting pulmonary metastases. CT and MRI are recommended if the patient has metastases of malignant gestational trophoblastic neoplasm.

Ultrasound is a useful non-invasive imaging method, especially when combined with serial hCG measurements in the diagnosis and management of gestational trophoblastic disease. In the presence of an elevated serum HCG titer, the absence of a gestational sac, and the characteristic sonographic appearance ("snowstorm pattern") with focal areas of hemorrhage, a complete hydatidiform mole is diagnosed. Ovarian theca lutein cysts are observed in up to $20 \%$ of patients with hydatidiform mole.

In some cases, gestational trophoblastic disease and retained products of conception can be difficult to distinguish sonographically (18). In that study the sonographic features that predicted GTD were a myometrial epicenter (Odds ratio [OR] = 28), depth of myometrial invasion of more than one third $(O R=20)$, placental venous lakes $(O R=$ 9), maximum mass dimensions of more than $3.45 \mathrm{~cm}$, and maximum endometrial thickness of less than $12 \mathrm{~mm}$. The remaining criteria were not statistically significant and included the characteristics of the mass, ascites, a "snowstorm" appearance, mass vascularity (including resistive index and peak systolic velocity), and the presence of ovarian cysts. They suggested that there are specific TVS findings that can accurately differentiate GTD and retained products of conception (18). 


\section{Conclusion}

Increasing information about histology of decidua, placenta and GTNs and the use of ultrasonography and other imaging modalities provides new opportunities for the physicians to evaluate many types of gynecologic and obstetrics patients.

\section{References}

1. Hansson SR, Bottalico B, Noskova V, Casslén B. Monoamine transporters in human endometrium and decidua. Hum Reprod Update. 2009 MarApr;15(2):249-60.

2. Khong TY. The pathology of placenta accreta, a worldwide epidemic. J Clin Pathol. 2008 Dec;61(12):1243-6.

3. Sanguansermsri $D$, Pongcharoen S. Pregnancy immunology: decidual immune cells. Asian Pac J Allergy Immunol. 2008 Jun-Sep;26(2-3):171-81.

4. Makrigiannakis A, Karamouti $M$, Drakakis $P$, Loutradis $D$, Antsaklis A. Fetomaternal immunotolerance. Am J Reprod Immunol. 2008 Dec;60(6):482-96.

5. Elsayes KM, Trout AT, Friedkin AM, Liu PS, Bude RO, Platt JF, Menias CO. Imaging of the placenta: a multimodality pictorial review. Radiographics. 2009 SepOct;29(5):1371-91.

6. Cetin A, Cetin M. Diagnostic and therapeutic decision-making with transvaginal sonography for first trimester spontaneous abortion, clinically thought to be incomplete or complete. Contraception. 1998 Jun;57(6):393-7.

7. Horowitz NS, Goldstein DP, Berkowitz RS. Management of gestational trophoblastic neoplasia. Semin Oncol. 2009 Apr;36(2):181-9.

8. Morgan JM, Lurain JR. Gestational trophoblastic neoplasia: an update. Curr Oncol Rep. 2008 Nov;10(6):497-504.

9. Shih IM, Seidman JD, Kurman RJ. Placental site nodule and characterization of distinctive types of intermediate trophoblast. Hum Pathol. 1999 Jun;30(6):68794.

10. Behtash N, Karimi Zarchi M. Placental site trophoblastic tumor. J Cancer Res Clin Oncol. 2008 Jan;134(1):1-6.

11. Berkowitz RS, Goldstein DP. Clinical practice. Molar pregnancy. N Engl J Med. 2009 Apr 16;360(16):1639-45.

12. Shih IM, Kurman RJ. The pathology of intermediate trophoblastic tumors and tumor-like lesions. Int J Gynecol Pathol. 2001 Jan;20(1):31-47.

13. Behtash N, Karimi Zarchi M. Placental site trophoblastic tumor. J Cancer Res Clin Oncol. 2008 Jan;134(1):1-6.

14. Palmer JE, Macdonald M, Wells M, Hancock BW, Tidy JA. Epithelioid trophoblastic tumor: a review of the literature. J Reprod Med. 2008 Jul;53(7):465-75.

15. Shih IM Gestational trophoblastic neoplasia--pathogenesis and potential therapeutic targets. Lancet Oncol. 2007 Jul;8(7):642-50.. 
16. Allen SD, Lim AK, Seckl MJ, Blunt DM, Mitchell AW. Radiology of gestational trophoblastic neoplasia. Clin Radiol. 2006 Apr;61(4):301-13.

17. Sumi Y, Ozaki Y, Shindoh N, Katayama H. Placental site trophoblastic tumor: imaging findings. Radiat Med. 1999 Nov-Dec;17(6):427-30.

18. Betel C, Atri M, Arenson AM, Khalifa M, Osborne R, Tomlinson G. Sonographic diagnosis of gestational trophoblastic disease and comparison with retained products of conception. J Ultrasound Med. 2006 Aug;25(8):985-93. 